\title{
Effect of Loosening Agent Sprays on the Efficiency of the Mechanical Harvesting of 'Arbequina' Olives
}

\author{
Antònia Ninot ${ }^{1}$ and Agustí Romero \\ Institut de Recerca i Tecnologia Agroalimentàries (IRTA), Mas de Bover, \\ Crta. Reus-El Morell, km 3,8, E-43120 Constantí, Spain
}

\author{
Joan Tous \\ Sant Antoni, 44, E-43480 Vilaseca, Spain
}

\author{
Ignasi Batlle \\ Institut de Recerca i Tecnologia Agroalimentàries (IRTA), Mas de Bover, \\ Crta. Reus-El Morell, km 3,8, E-43120 Constantí, Spain
}

Additional index words. ethephon, monopotassium phosphate, monoammonium phosphate, Olea europaea

\begin{abstract}
The aim of this work was to evaluate the effect of ethephon (2-chloroethylphosponic acid), applied either alone or in combination with phosphorus compounds, on olive trees (Olea europaea L.) to improve the efficiency of mechanical harvesting. The trial was carried out in mature 'Arbequina' olive trees located in northeast Spain during the 2007 and 2008 olive crop seasons. In 2007, the olive trees were sprayed with 300 or $500 \mathrm{mg} \cdot \mathrm{L}^{-1}$ of ethephon combined with two phosphoric formulations: monopotassium phosphate (MKP), at $15 \mathrm{~g} \cdot \mathrm{L}^{-1}$ or $30 \mathrm{~g} \cdot \mathrm{L}^{-1}$ and monoammonium phosphate at $15 \mathrm{~g} \cdot \mathrm{L}^{-1}$. In 2008 olive trees were sprayed with two ethephon concentrations $\left(150\right.$ or $\left.300 \mathrm{mg} \cdot \mathrm{L}^{-1}\right)$ in combination with $15 \mathrm{~g} \cdot \mathrm{L}^{-1}$ or $30 \mathrm{~g} \cdot \mathrm{L}^{-1} \mathrm{MKP}$ or alone. Harvesting was performed with a commercial trunk shaker. Data were analyzed as a randomized complete block design with eight replications. Fruit removal force (FRF), ripeness index, fruit weight, natural drop, shaking efficiency (SE), leaf drop (LD), oil content, and bloom intensity of the next year's bloom were measured. The trial treatments did not significantly affect ripeness index or oil content. Ethephon reduced FRF and increased shaking efficiency with significant differences. $P$ compounds did not seem to affect FRF and LD. Small amounts of ethephon $\left(150 \mathrm{mg} \cdot \mathrm{L}^{-1}\right)$ caused a large degree of fruit loosening $(\mathrm{a} 77 \%$ reduction in FRF at 11 days), which was sufficient to improve the efficiency of mechanical harvesting with minimal leaf drop.
\end{abstract}

Olive oil production is mainly located around the Mediterranean Basin and some others areas of Mediterranean climate (e.g., Australia, Argentina, California, Chile). Hand harvesting of olives (Olea europaea L.) for oil represents more than $50 \%$ of their total production cost (Barranco et al., 2004; Tous and Romero, 1992). Although mechanical continuous harvesting is quite efficient in many high-density orchards, olive tree shakers are normally much less efficient in traditional orchards with large trees and in some cultivars (Pastor et al., 2001; Tous et al., 2007). Lavee et al. (1982) suggested that shaker efficiency also depends on maturity stage, fruit load, and especially cultivar characteristics. 'Arbequina' is the most important olive variety grown in traditional Catalan orchards. This cultivar is characterized by small fruits and a weeping-open growing habit that reduces the energy transmitted through trunk vibration to the fruit (Tous and Romero, 1992).

Received for publication 18 Apr. 2012. Accepted for publication 6 Aug. 2012.

${ }^{1}$ To whom reprint requests should be addressed; e-mail antonia.ninot@irta.cat.
The use of ethylene-releasing chemicals to increase removal rates of mechanical shakers has been widely studied in many countries and for many years (Lavee and Haskal, 1975; Martin et al., 1981; Tous et al., 1995; Vitagliano, 1975). However, removal efficiency in research trials using ethylenereleasing chemicals has been erratic (Martin et al., 1981), perhaps as a result of the variability in loosing product uptake and breakdown under natural conditions (Denney and Martin, 1994; Lavee and Haskal, 1975). In addition, environmental factors, including temperature, relative humidity ( $\mathrm{RH})$, and plant stress, have a great influence on the ethephon response (Klein et al., 1978; Martin et al., 1981).

Ethephon causes leaf abscission, which can compromise the next year's production if more than $15 \%$ to $20 \%$ of the leaves are lost (Martin et al., 1981). Leaves also have different thresholds of sensitivity according to their maturity; mature leaves ( 25 to 28 months old) respond faster to external ethylene application than younger ones (Goren et al., 1998). Furthermore, olive fruits and leaves exhibit different thresholds of sensitivity and different absorption and diffusion rates when exposed to exogenous ethylene (Blumenfeld et al., 1978; Denney and Martin, 1994; Lang and Martin, 1985). Lang and Martin (1989) reported that low ethylene concentration could reduce leaf abscission with an acceptable degree of fruit loosening, but for several cultivars, this would not be enough to guarantee efficient and economical mechanical harvesting. Many compounds, other than ethylene, have also been studied as loosening agents for olive fruits, but many proved less efficient at reducing the force required for fruit removal (Barranco et al., 2004; Ben-Tal, 1987; Burns et al., 2008; Denney and Martin, 1994; Hartmann et al., 1976; Martin et al., 1981). Banno et al. (1993) demonstrated that a foliar spray treatment with phosphoruscontaining compounds causes olive fruit abscission with minimal leaf loss. In addition, phosphorus compounds act independently of endogenous ethylene action in inducing leaf abscission in olive trees (Goren et al., 1998; Yamada and Martin, 1994). It has recently been reported that applying MKP alone, or in combination with ethephon, reduces the fruit removal force of olives (Barranco et al., 2004; Burns et al., 2008). Taken as a whole, these studies suggest that each ethephon-P compound combination needs be tested at each site as a result of the great influence that environmental conditions have over obtaining maximum shaking efficiency with minimum defoliation.

The objective of this study was to evaluate the potential of ethephon (2-chloroethyl phosphonic acid) in combination with $\mathrm{P}$ formulation compounds as an agent for loosening olive fruits and improving the efficiency of the mechanical harvesting of mature 'Arbequina' olive trees under the typical environment conditions found in Catalonia.

\section{Materials and Methods}

Plant material and experimental plot characteristics. The study was carried out during the 2007 and 2008 olive crop seasons in a traditional olive orchard at IRTA-Mas de Bover, located in Constantí, Tarragona, Spain (lat. $41^{\circ} 10^{\prime} 13^{\prime \prime} \mathrm{N}$, long. $1^{\circ} 10^{\prime} 04^{\prime \prime} \mathrm{W}$, altitude $108 \mathrm{~m}$ ). The local climate is Mediterranean with average annual rainfall of $556 \mathrm{~mm}$. The trees were 80-year-old 'Arbequina' olive trees with an average diameter at $40 \mathrm{~cm}$ above the ground at $44.2 \mathrm{~cm}$. The plot had an alkaline soil with a sandy loam texture. The orchard was managed in rain-fed conditions and weeds were controlled by pre- and post-emergence herbicide applications.

Environmental parameters (temperature and $\mathrm{RH}$ ) were recorded at 30-min intervals, throughout the field trial, using two data loggers (HOBO, Rickly) located in the same orchard. Rainfall and wind velocity were monitored with an automatic weather station (Campbell Scientific Ltd., Leicester, U.K.) located $50 \mathrm{~m}$ from the trial.

Treatments and experimental design. The trees were sprayed with ethephon formulated as CLOUD (Sapec-Agro, Reus, Spain). The spray solution was applied with a hand-gun 
sprayer at a rate of $9.8 \pm 1.3 \mathrm{~L} /$ tree to the point of runoff.

In 2007 the treatments evaluated were:

Untreated control (sprayed with water) $300 \mathrm{mg} \cdot \mathrm{L}^{-1}$ ethephon $+15 \mathrm{~g} \cdot \mathrm{L}^{-1}$ monoammonium phosphate (MAP; $12 \mathrm{~N}-61 \mathrm{P}-0 \mathrm{~K}$ )

$300 \mathrm{mg} \cdot \mathrm{L}^{-1}$ ethephon $+30 \mathrm{~g} \cdot \mathrm{L}^{-1} \mathrm{MKP}$ $(0 \mathrm{~N}-52 \mathrm{P}-34 \mathrm{~K})$

$300 \mathrm{mg} \cdot \mathrm{L}^{-1}$ ethephon $+30 \mathrm{~g} \cdot \mathrm{L}^{-1} \mathrm{MKP}$

$500 \mathrm{mg} \cdot \mathrm{L}^{-1}$ ethephon $+15 \mathrm{~g} \cdot \mathrm{L}^{-1}$ MAP

$500 \mathrm{mg} \cdot \mathrm{L}^{-1}$ ethephon $+15 \mathrm{~g} \cdot \mathrm{L}^{-1} \mathrm{MKP}$

$500 \mathrm{mg} \cdot \mathrm{L}^{-1}$ ethephon $+30 \mathrm{~g} \cdot \mathrm{L}^{-1} \mathrm{MKP}$

In 2008, in view of the results obtained in the previous year, the treatments were modified and the trees were sprayed with lower concentrations of ethephon. The treatments evaluated were:

Untreated control (sprayed with water)

$0 \mathrm{mg} \cdot \mathrm{L}^{-1}$ ethephon $+30 \mathrm{~g} \cdot \mathrm{L}^{-1} \mathrm{MKP}$

$150 \mathrm{mg} \cdot \mathrm{L}^{-1}$ ethephon $+30 \mathrm{~g} \cdot \mathrm{L}^{-1} \mathrm{MKP}$

$300 \mathrm{mg} \cdot \mathrm{L}^{-1}$ ethephon

$300 \mathrm{mg} \cdot \mathrm{L}^{-1}$ ethephon $+15 \mathrm{~g} \cdot \mathrm{L}^{-1} \mathrm{MKP}$

$300 \mathrm{mg} \cdot \mathrm{L}^{-1}$ ethephon $+30 \mathrm{~g} \cdot \mathrm{L}^{-1} \mathrm{MKP}$

The volume sprayed for each olive tree was $0.2 \mathrm{~L} \cdot \mathrm{m}^{-2}$ of external surface (ES). The area of the ES was calculated from the perpendicular diameter of each tree and the height of the canopy measured as: $\operatorname{ES}\left(\mathrm{m}^{2}\right)=$ $\pi *\left\{\left[\left(D_{1}+D_{2}\right) / 2\right]^{*} H\right\}$, where $D_{1}$ was maximum diameter, $\mathrm{D}_{2}$ was minimum diameter, and $\mathrm{H}$ was canopy height. The average external surface of the olive trees was $48.8 \pm 6.7$ $\mathrm{m}^{2} /$ tree. Considering a plant density of 100 tree/ha, the volume sprayed was $976 \mathrm{~L} \cdot \mathrm{ha}^{-1}$.

The experimental design was a randomized complete block with eight replications of one olive tree per block and treatment. In 2007 , seven treatments were tested (one untreated control and six different treatments). In 2008, six treatments were tested (one untreated control and five different treatments). The spray treatments were applied on 14 Nov. in 2007 and on 13 Nov. in 2008 when the ripeness index was $\approx 4.2$ and 2.2 in 2007 and 2008, respectively (Uceda and Frias, 1975).

Environmental conditions are summarized in Table 1. Temperatures during the trial were cooler in 2007 than in 2008, but similar environmental conditions were observed on the day on which the olive trees were sprayed. The cumulative rainfalls during the month before spray application were $25.8 \mathrm{~mm}$ in the first year and $223.9 \mathrm{~mm}$ in the second.

Fruit removal force. The FRF from its pedicel was measured in cent Newton $(\mathrm{cN})$ of force using a dynamometer (Correx, Bern, Switzerland). Fruits that dropped without being attached to the dynamometer were each assigned an FRF of $0 \mathrm{cN}$. Fifty fruits per tree were detached just before applying the spray treatment and also 5 and $13 \mathrm{~d}$ after application in 2007 and 5 and $11 \mathrm{~d}$ after application in 2008. The average FRF was 530 and $456 \mathrm{cN}$ in the initial conditions of the trial in 2007 and 2008, respectively.

Table 1. Environmental conditions on the day of ethephon application and overall average field trial and values for crop production, ripeness index, fruit weight, and the relation between fruit removal force (FRF) and fruit weight at the beginning of the trial for 2007 and 2008.

\begin{tabular}{lcc}
\hline Parameters & 2007 & 2008 \\
\hline Day of ethephon application & 14 Nov. & Nov. \\
Minimum temperature $\left({ }^{\circ} \mathrm{C}\right)$ & 4.6 & 4.4 \\
Average temperature $\left({ }^{\circ} \mathrm{C}\right)$ & 11.2 & 10.9 \\
Maximum temperature $\left({ }^{\circ} \mathrm{C}\right)$ & 19.2 & 6.3 \\
Relative humidity $(\%)$ & 63 & 60 \\
& & 13 to 24 Nov. \\
For whole trial period & 14 to 27 Nov. & 1.8 \\
Minimum temperature $\left({ }^{\circ} \mathrm{C}\right)$ & -4.3 & 10.7 \\
Average temperature $\left({ }^{\circ} \mathrm{C}\right)$ & 8.9 & 21.1 \\
Maximum temperature $\left({ }^{\circ} \mathrm{C}\right)$ & 20.4 & 70 \\
Relative humidity $(\%)$ & 65 & 223.9 \\
Accumulated rainfall one month before spraying $(\mathrm{mm})$ & 25.8 & 46 \\
Average yield $(\mathrm{kg} /$ tree) & 28 & 2.2 \\
Ripeness index & 4.2 & 1.5 \\
Fruit weight $(\mathrm{g})$ & 1.7 & 304 \\
FRF/weight $\left(\mathrm{cN} \cdot \mathrm{g}^{-1}\right)$ & 313 & \\
\hline
\end{tabular}

${ }^{\mathrm{z}}$ Ripeness index (within a range 0 to 7 ) as described by Uceda and Frias (1975).

Ripeness index and oil content. The olive ripeness index was determined according to the method proposed by Uceda and Frias (1975) based on an evaluation of olive skin and flesh color. The average weight and ripeness indices were based on 50 olives that were analyzed just before applying the treatment and then 14 and $11 \mathrm{~d}$ after applying it in 2007 and 2008, respectively. In 2007, two samples were taken at harvest: olives removed by the shaker and those hand-harvested after shaking.

In 2007 , a 1-kg sample of mechanically harvested fruits was milled and the paste obtained was oven-dried at $105^{\circ} \mathrm{C}$ to a constant weight. The resulting fatty dried paste from each replicate and treatment was weighed in a paper capsule and the oil was chemically extracted with petroleum ether (40 to $60{ }^{\circ} \mathrm{C}$ ) using the Soxhlet method to evaluate the total oil content of the paste. The oil content was expressed as a percentage of the fruit dry weight. Two replicates from each of eight olive trees per treatment were analyzed.

Natural drop, shaking efficiency, and leaf drop. In 2007 and 2008, olives that dropped from trees before harvesting (natural drop) were collected from the ground under each tree and weighed (fresh weight). In 2007, olive trees were shaken $14 \mathrm{~d}$ after spraying when fruit removal force averaged less than $300 \mathrm{cN}$. Mechanical harvesting consisted of one 10-s trunk vibration per olive tree. Fruits not removed by shaking were hand-picked to determine total yield and harvester efficiency. In both cases, LD during harvest were also weighed (fresh weight). In 2008, as a result of the large number of olives dropped before harvest $(46 \%)$, fruits were harvested manually $11 \mathrm{~d}$ after spraying and leaf drop was visually scored as a tree defoliation intensity on a scale of 0 to 5 , where $5=$ heavy defoliation and $0=$ no defoliation

In 2007 the efficiency of mechanical harvesting was calculated as a percentage of the fruits removed: SE $(\%)=($ weight of mechanically harvested fruit* $100 /$ total fruit weight).
Dropped leaf data were expressed as grams of fresh weight per canopy volume $(\mathrm{CV})$ in 2007: $\mathrm{CV}\left(\mathrm{m}^{3}\right)=4 / 3 \pi\left(\mathrm{D}_{1} / 2 * \mathrm{D}_{2} / 2 * \mathrm{H} / 2\right)$, where $\mathrm{D}_{1}$ was maximum diameter, $\mathrm{D}_{2}$ was minimum diameter, and $\mathrm{H}$ was canopy height.

Bloom intensity. In May 2008 and 2009, to assess the possible effects of leaf drop on the next year's bloom, the level of flowering intensity was visually scored on a scale of 0 to 5 , where $5=$ heavy bloom and $0=$ no bloom.

Statistical analysis. Data were statistically analyzed using SAS software (SAS Institute, Cary, NC). One-way analysis of variance was carried out on all data for each variable studied. If a significant $(P \leq 0.05)$ effect was obtained, separation of the means was carried out using the Duncan multiple range test $(P \leq 0.05)$.

\section{Results}

Fruit removal force. The ethephon treatments reduced the fruit removal force. In 2007, the FRF just before application was higher than $500 \mathrm{cN}$ in all cases (Fig. 1A). Five days after application, no significant differences were found between treatments. Thirteen days after ethephon application, FRF values were significantly different for the different treatments. Although the reduction in FRF for the control trees was only $25 \%$, the reduction in FRF after ethephon application ranged from $58 \%$ for $300 \mathrm{mg} \cdot \mathrm{L}^{-1}+15 \mathrm{~g} \cdot \mathrm{L}^{-1}$ MAP to $71 \%$ for $500 \mathrm{mg} \cdot \mathrm{L}^{-1}$ combined with $15 \mathrm{~g} \cdot \mathrm{L}^{-1} \mathrm{MKP}$ (Table 2).

In 2008, values of FRF just before ethephon application were more than $450 \mathrm{cN}$ in all cases (Fig. 1B). However, 5 and $11 \mathrm{~d}$ after application, significant differences between treatments were found. Untreated trees and trees sprayed only with MKP had the highest FRF values. FRF values for olives treated with ethephon, regardless of the concentration, were significantly lower than for olives not treated with ethephon. The maximum decrease in FRF (Table 2) was associated with the application of $300 \mathrm{mg} \cdot \mathrm{L}^{-1}+15 \mathrm{~g} \cdot \mathrm{L}^{-1} \mathrm{MKP}$ ( $65 \%$ and $82 \%$ after 5 and $11 \mathrm{~d}$, respectively). 

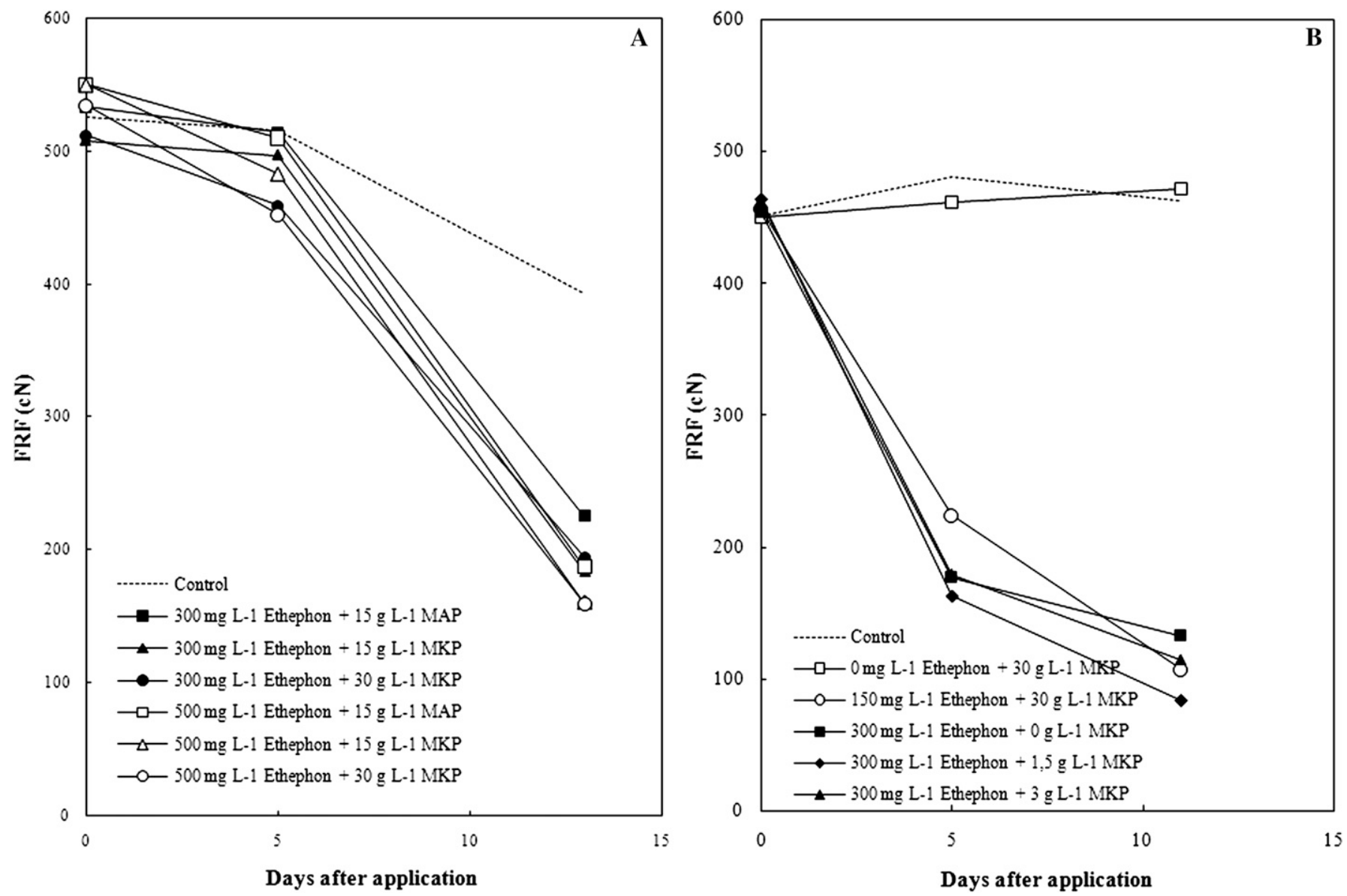

Fig. 1. Effect of ethephon treatment, applied either in combination with P compounds or alone, on fruit removal force (FRF). (A) In 2007 at 0,5 , and $13 \mathrm{~d}$ after treatment application. (B) In 2008 at 0, 5, and $11 \mathrm{~d}$ after treatment application. Analysis of variance and Duncan's mean separation test were applied. Means followed by the same letter are not significantly different $(P \leq 0.05)$. Absence of letters indicates that no statistical significance was found.

Table 2. Effect of ethephon treatment, applied either in combination with P compounds or alone, on fruit removal force (FRF) used as a loosening agent for olive fruits.

\begin{tabular}{|c|c|c|c|c|c|c|}
\hline \multirow{2}{*}{ Treatment } & \multicolumn{6}{|c|}{$\mathrm{FRF}(\mathrm{cN})$} \\
\hline & \multicolumn{3}{|c|}{2007} & \multicolumn{3}{|c|}{2008} \\
\hline Control & 526 & $516(2 \%)^{y}$ & 393 a $(25 \%)$ & 451 & 481 a $(0 \%)$ & 463 a $(0 \%)$ \\
\hline $150 \mathrm{mg} \cdot \mathrm{L}^{-1}$ ethephon $+30 \mathrm{~g} \cdot \mathrm{L}^{-1} \mathrm{MKP}$ & - & - & - & 456 & $224 \mathrm{~b}(51 \%)$ & $107 \mathrm{~b}(77 \%)$ \\
\hline $300 \mathrm{mg} \cdot \mathrm{L}^{-1}$ ethephon $+15 \mathrm{~g} \mathrm{~L}^{-1} \mathrm{MAP}$ & 533 & $514(4 \%)$ & $225 \mathrm{~b}(58 \%)$ & - & - & - \\
\hline $300 \mathrm{mg} \cdot \mathrm{L}^{-1}$ ethephon $+0 \mathrm{~g} \cdot \mathrm{L}^{-1} \mathrm{MKP}$ & - & - & & 454 & $177 \mathrm{~b}(61 \%)$ & $133 \mathrm{~b}(71 \%)$ \\
\hline $300 \mathrm{mg} \cdot \mathrm{L}^{-1}$ ethephon $+15 \mathrm{~g} \cdot \mathrm{L}^{-1} \mathrm{MKP}$ & 508 & $497(2 \%)$ & $183 \mathrm{bc}(64 \%)$ & 464 & 162 b $(65 \%)$ & $83 \mathrm{~b}(82 \%)$ \\
\hline $500 \mathrm{mg} \cdot \mathrm{L}^{-1}$ ethephon $+15 \mathrm{~g} \cdot \mathrm{L}^{-1} \mathrm{MKP}$ & 550 & $483(12 \%)$ & 160 c $(71 \%)$ & - & - & - \\
\hline $500 \mathrm{mg} \cdot \mathrm{L}^{-1}$ ethephon $+30 \mathrm{~g} \cdot \mathrm{L}^{-1} \mathrm{MKP}$ & 534 & $452(15 \%)$ & 159 c $(70 \%)$ & - & - & - \\
\hline Significance $^{z}$ & NS & NS & $* *$ & NS & $* *$ & $* *$ \\
\hline
\end{tabular}

z**High significance effect $P<0.001 ;$ NS $=$ nonsignificant.

${ }^{\mathrm{y}}$ In parentheses the FRF reduction percentage achieved.

$\mathrm{MKP}=$ monopotassium phosphate $\mathrm{MAP}=$ monoammonium phosphate.

Ripeness index and oil content. Ethephon application had no effect on either ripeness index or oil content (data not shown). The olive is not a climacteric fruit and ethephon application had no influence on the ripening of olives once the maximum respiratory ratio had been attained (Rugini et al., 1982).

Natural drop, shaking efficiency, and leaf drop. In 2007, the application of ethephon combined with $\mathrm{P}$ compounds clearly improved the efficiency of trunk shaking $14 \mathrm{~d}$ after application (Table 3). SE reached levels up to $76 \%$ for treated olive trees as opposed to $57 \%$ for the control trees. The percentage of unremoved olive fruits, which were later picked by hand, differed significantly between treatments. The highest percentage of fruit retained after mechanical harvest was associated with the control, whereas values for sprayed trees ranged from $11 \%$ to $19 \%$ without any significant difference between ethephon concentrations.

In 2008, strong winds blew (wind velocity $=$ $\left.22.7 \mathrm{~m} \cdot \mathrm{s}^{-1}\right) 9 \mathrm{~d}$ after the treatment was applied and many olives dropped from the trees (Table 3). For trees that had not been treated with ethephon, fruit losses were $6 \%$ to $7 \%$, but for ethephon-treated trees, fruit losses reached as much as $61 \%$ of total yield. The maximum losses were associated with applications of 
Table 3. Effect of ethephon treatment, applied either in combination with P compounds or alone, on natural drop, shaking efficiency (SE), and unremoved fruits as a loosening agent for olive fruits.

\begin{tabular}{|c|c|c|c|c|c|c|c|}
\hline \multirow[b]{2}{*}{ Treatment } & \multicolumn{4}{|c|}{2007} & \multicolumn{3}{|c|}{$2008^{y}$} \\
\hline & $\begin{array}{l}\text { Total crop } \\
\text { (kg/tree) }\end{array}$ & $\begin{array}{c}\text { Natural drop } \\
\text { before shaking }(\%)\end{array}$ & $\begin{array}{c}\text { Shaking efficiency } \\
(\mathrm{SE})^{\mathrm{x}}(\%)\end{array}$ & $\begin{array}{l}\text { Unremoved } \\
\text { fruits }^{\mathrm{w}}(\%)\end{array}$ & $\begin{array}{l}\text { Total crop } \\
\text { (kg/tree) }\end{array}$ & $\begin{array}{c}\text { Natural drop } \\
\text { before shaking }(\%)\end{array}$ & $\begin{array}{l}\text { Unremoved } \\
\text { fruits }(\%)\end{array}$ \\
\hline Control & 23.0 & 3.3 & $57.0 \mathrm{~b}$ & $39.7 \mathrm{a}$ & 49.4 & $5.6 \mathrm{c}$ & $94.4 \mathrm{a}$ \\
\hline $0 \mathrm{mg} \cdot \mathrm{L}^{-1}$ ethephon $+3 \% \mathrm{MKP}$ & - & - & - & - & 51.3 & $7.4 \mathrm{c}$ & $92.6 \mathrm{a}$ \\
\hline $150 \mathrm{mg} \cdot \mathrm{L}^{-1}$ ethephon $+3 \% \mathrm{MKP}$ & - & - & - & - & 43.5 & $46.1 \mathrm{~b}$ & $53.9 \mathrm{~b}$ \\
\hline $300 \mathrm{mg} \cdot \mathrm{L}^{-1}$ ethephon $+1.5 \%$ MAP & 32.1 & 16.1 & $67.9 \mathrm{ab}$ & $16.0 \mathrm{~b}$ & - & - & - \\
\hline $300 \mathrm{mg} \cdot \mathrm{L}^{-1}$ ethephon $+0 \% \mathrm{MKP}$ & - & - & - & - & 40.8 & $54.5 \mathrm{a}$ & $45.5 \mathrm{c}$ \\
\hline $300 \mathrm{mg} \cdot \mathrm{L}^{-1}$ ethephon $+1.5 \% \mathrm{MKP}$ & 24.6 & 8.6 & $72.1 \mathrm{a}$ & $19.3 \mathrm{~b}$ & 48.4 & $61.0 \mathrm{a}$ & $39.0 \mathrm{c}$ \\
\hline $300 \mathrm{mg} \cdot \mathrm{L}^{-1}$ ethephon $+3 \%$ MKP & 23.3 & 7.5 & $73.2 \mathrm{a}$ & $19.4 \mathrm{~b}$ & 42.8 & $55.9 \mathrm{a}$ & $44.1 \mathrm{c}$ \\
\hline $500 \mathrm{mg} \cdot \mathrm{L}^{-1}$ ethephon $+1.5 \%$ MAP & 33.6 & 11.3 & $75.5 \mathrm{a}$ & $13.2 \mathrm{~b}$ & - & - & - \\
\hline $500 \mathrm{mg} \cdot \mathrm{L}^{-1}$ ethephon $+1.5 \%$ MKP & 30.7 & 12.6 & $71.0 \mathrm{a}$ & $16.4 \mathrm{~b}$ & - & - & - \\
\hline $500 \mathrm{mg} \cdot \mathrm{L}^{-1}$ ethephon $+3 \% \mathrm{MKP}$ & 27.2 & 12.9 & $76.1 \mathrm{a}$ & $11.0 \mathrm{~b}$ & - & - & - \\
\hline Significance $^{z}$ & NS & NS & $*$ & $* *$ & NS & $* *$ & $* *$ \\
\hline
\end{tabular}

z**High significance effect $P>0.001$; *low significance effect $P>0.05$; NS $=$ nonsignificant.

${ }^{y}$ Strong winds blew the ninth day after treatment were applied. As a result of the great number of olives that dropped preharvest, fruits were harvested manually $11 \mathrm{~d}$ after spraying.

${ }^{\mathrm{x}}$ Mechanical harvesting consisted of one 10 -s trunk vibration per olive tree $14 \mathrm{~d}$ after spraying.

${ }^{\mathrm{w}}$ Fruits not removed by shaking were hand-picked.

$\mathrm{MKP}=$ monopotassium phosphate; MAP = monoammonium phosphate.

$300 \mathrm{mg} \cdot \mathrm{L}^{-1}+15 \mathrm{~g} \cdot \mathrm{L}^{-1} \mathrm{MKP}$ (the treatment that had the lowest FRF value).

However, ethephon also caused LD (Table 4). In 2007, total LD significantly varied between treatments with control values being significantly different from the others. The concentration of $500 \mathrm{mg} \cdot \mathrm{L}^{-1}$ of ethephon induced more total LD than that of $300 \mathrm{mg} \cdot \mathrm{L}^{-1}$. The application of $\mathrm{P}$ compounds had no effect on total LD. The highest LD was found at $500 \mathrm{mg} \cdot \mathrm{L}^{-1}$ in combination with any dose of $\mathrm{P}$ compound.

In 2008, it was not possible to weigh the dropped leaves as a result of the wind carrying the leaves far from their respective trees. To assess LD for that year, a visual assessment of olive tree defoliation was made. Trees that had not been treated with ethephon presented lower defoliation rates (Table 4) and these were significantly different from rates for ethephon-treated trees. The maximum level of defoliation was associated with the $300 \mathrm{mg} \cdot \mathrm{L}^{-1}+15 \mathrm{~g} \cdot \mathrm{L}^{-1} \mathrm{MKP}$ treatment.

Bloom intensity. No differences were found for any of the ethephon treatments on bloom induction in the next spring (2008) after the first year of the trial (Table 4). In 2009, the ethephon treatment of 2008 reduced bloom induction significantly. The results suggested a close correlation between LD and blooming intensity.

\section{Discussion}

Spraying olive trees with low ethephon concentrations, either alone or in combination with $\mathrm{P}$ compounds, reduced the FRF of 'Arbequina' olives. The efficiency of the shaker (SE) for mechanical harvesting increased when ethephon spraying was applied.

The results obtained from this study of SE using a mechanical shaker included higher olive dropping values than previous trials conducted under similar conditions (Tous et al., 1995). This trial obtained efficiencies below $78 \%$ with high levels of LD. In addition, the control trees presented an efficiency level

Table 4. Effect of ethephon treatment, applied either in combination with P compounds or alone, on leaf drop (LD), defoliation intensity, and bloom intensity as a loosening agent for olive fruits.

\begin{tabular}{lcccc}
\hline & $\begin{array}{c}\text { Total LD 2007 } \\
\text { Treatment }\end{array}$ & $\begin{array}{c}\text { Defoliation intensity } \\
\left(\mathrm{g} \cdot \mathrm{m}^{-3}\right)\end{array}$ & $2008^{\mathrm{z}}$ & \multicolumn{2}{c}{ Bloom intensity } \\
\cline { 3 - 6 } Control & $38.5 \mathrm{~d}$ & $0.3 \mathrm{c}$ & 3.9 & $3.0 \mathrm{a}$ \\
$0 \mathrm{mg} \cdot \mathrm{L}^{-1}$ ethephon $+3 \%$ MKP & - & $0.9 \mathrm{c}$ & - & $2.0 \mathrm{ab}$ \\
$150 \mathrm{mg} \cdot \mathrm{L}^{-1}$ ethephon $+3 \%$ MKP & - & $2.4 \mathrm{~b}$ & - & $1.5 \mathrm{~b}$ \\
$300 \mathrm{mg} \cdot \mathrm{L}^{-1}$ ethephon $+1.5 \%$ MAP & $92.9 \mathrm{bc}$ & - & 3.8 & - \\
$300 \mathrm{mg} \cdot \mathrm{L}^{-1}$ ethephon $+0 \%$ MKP & - & $3.3 \mathrm{ab}$ & - & $1.3 \mathrm{~b}$ \\
$300 \mathrm{mg} \cdot \mathrm{L}^{-1}$ ethephon $+1.5 \% \mathrm{MKP}$ & $85.0 \mathrm{bc}$ & $3.6 \mathrm{a}$ & 3.6 & $1.1 \mathrm{~b}$ \\
$300 \mathrm{mg} \cdot \mathrm{L}^{-1}$ ethephon $+3 \% \mathrm{MKP}$ & $77.5 \mathrm{c}$ & $3.1 \mathrm{ab}$ & 3.4 & $1.6 \mathrm{~b}$ \\
$500 \mathrm{mg} \cdot \mathrm{L}^{-1}$ ethephon $+1.5 \% \mathrm{MAP}$ & $135.9 \mathrm{a}$ & - & 2.9 & - \\
$500 \mathrm{mg} \cdot \mathrm{L}^{-1}$ ethephon $+1.5 \% \mathrm{MKP}$ & $109.0 \mathrm{ab}$ & - & 3.3 & - \\
$500 \mathrm{mg} \cdot \mathrm{L}^{-1}$ ethephon $+3 \% \mathrm{MKP}$ & $125.8 \mathrm{a}$ & - & 3.3 & - \\
Significance & $* *$ & $* *$ & $\mathrm{NS}$ & $*$ \\
\hline
\end{tabular}

${ }^{2}$ Defoliation intensity: $5=$ heavy defoliation, and $0=$ no defoliation.

'Bloom intensity: $5=$ heavy bloom, and $0=$ no bloom.

x**High significance effect $P>0.001$; *low significance effect $P>0.05$; NS $=$ nonsignificant.

$\mathrm{MKP}=$ monopotassium phosphate; $\mathrm{MAP}=$ monoammonium phosphate.

of $57 \%$, which was a common value for traditional 'Arbequina' orchards in Catalonia (Solé and Florensa, 1997; Tous et al., 1995). Spraying olive trees with reduced doses of ethephon in combination with $\mathrm{P}$ fertilizers increased SE by almost $20 \%$. These ratios are economically profitable for mechanical harvesting in traditional olive orchards. Furthermore, changing tree shape and reducing canopy size, by pruning, will improve mechanical harvesting efficiency (Pastor et al., 2001; Tous et al., 1995; Tous and Romero, 1992).

The lower value of FRF at the beginning of the trial together with high tissue hydration could have promoted better ethephon penetration in 2008 (Denney and Martin, 1994) and, in only $5 \mathrm{~d}$, reduced the FRF to less than $2.95 \mathrm{~N}$, clearcut between fruit abscission and non-abscission (Lang and Martin, 1989).

The LD observed in 2007 did not affect either the following blooming intensity or the following crop yield (2008). This could have been as a result of ethephon promoting the abscission of senescent leaves, as reported by Lang and Martin (1989). Even so, young leaves seemed to remain on the trees together with the buds. The level of defoliation observed in 2007 at the higher dose of treatments was equivalent to those found by Tous et al. (1995) reaching up to $136 \mathrm{~g} \cdot \mathrm{m}^{-3}$ (27\%). In Spring of 2009 , the blooming intensity reduced in olive trees treated with ethephon, suggesting an accumulative effect of LD when the olive trees were sprayed during two consecutive years.

Treatments have been effective in reducing FRF both with a ripeness index of 4.2 in 2007 and 2.2 in 2008.

The trial conducted in 2008 allows found that the MKP had no added effect to the ethephon in reducing the FRF. In 2007 there was no difference between MAP and MKP, which may indicate that the MAP did not have any effect in reducing the FRF. These results were not in agreement with Burns et al. (2008), as the authors of this work pointed out. Ethephon applications with MKP had an influence on the FRF and leaf drop although they used a dose of ethephon and MKP much higher than those of our trial.

The application of ethephon on mature olive trees was effective in reducing FRF and it improved the SE at harvest. Moreover, handling of the product is difficult and complicated, especially in windy areas at the time 
of harvest. It is not advisable to use this product in traditional olive cultivation regions where the risk of gales at harvest time is significant.

Although many studies have already been done to investigate ways of improving fruit removal by mechanical harvesting, more work is still needed to prevent the erratic results obtained when ethephon sprays are applied to olive trees. No previous field trials have reported such large reductions in FRF associated with the application of such low concentrations of ethephon. Small applications of ethephon $\left(150 \mathrm{mg} \cdot \mathrm{L}^{-1}\right)$ promoted sufficient fruit loosening to improve SE with minimum leaf drop. Ethephon application seems more efficient in the "on" year than "off" year, but more research is needed to confirm this.

\section{Literature Cited}

Banno, K., O. Martin, G.C. Navarro, and R.M. Carlson. 1993. The role of phosphorus as an abscission-inducing agent for olive leaves and fruit. J. Amer. Soc. Hort. Sci. 118:599-604.

Barranco, D., O. Arquero, C. Navarro, and H.F. Rapoport. 2004. Monopotassium phosphate for olive fruit abscission. HortScience 39:13131314.

Ben-Tal, Y. 1987. Improving ethephon's effect on olive fruit abscission by glycerine. HortScience 22:869-871.

Blumenfeld, A., E. Epstein, and Y. Ben-Tal. 1978. Ethylene treatment and abscission of olive fruits. HortScience 13:47-48.
Burns, J.K., L. Ferguson, K. Glozer, W.H. Krueger, and R.C. Rosecrane. 2008. Screening fruit loosening agents for black ripe processed table olives. HortScience 43:1449-1453.

Denney, J.O. and G.C. Martin. 1994. Ethephon tissue penetration and harvest effectiveness in olive as a function of solution $\mathrm{pH}$, application time, and BA or NAA addition. J. Amer. Soc. Hort. Sci. 119:1185-1192.

Goren, R., M. Huberman, and G.C. Martin. 1998 Phosphorus-induced leaf abscission in detached shoots of olive and citrus. J. Amer. Soc. Hort. Sci. 123:545-549.

Hartmann, H.T., W. Reed, and K. Opitz. 1976. Promotion of olive fruit abscission with 2-chloroethyl-tris-(2-methoxyethoxy)-silane. J. Amer. Soc. Hort. Sci. 101:278-281.

Klein, I., E. Epstein, S. Lavee, and Y. Ben-Tal. 1978. Environmental-factors affecting ethephon in olive. Sci. Hort. 9:21-30.

Lang, G.A. and G.C. Martin. 1985. Ethylenereleasing compounds and the laboratory modeling of olive fruit abscission vs. ethylene release. J. Amer. Soc. Hort. Sci. 110:207-211.

Lang, G.A. and G.C. Martin. 1989. Olive organ abscission-Fruit and leaf response to applied ethylene. J. Amer. Soc. Hort. Sci. 114:134138.

Lavee, S., B. Avidan, and Y. Ben-Tal. 1982. Effect of fruit size and yield on the fruit-removalforce within and between olive cultivars. Sci. Hort. 17:27-32.

Lavee, S. and A. Haskal. 1975. Studies with ethephon for facilitating olive harvest. Sci. Hort. 3:163-172.

Martin, G.C., S. Lavee, and G.S. Sibbett. 1981. Chemical loosening agents to assist mechanical harvest of olive. J. Amer. Soc. Hort. Sci. 106: 325-330

Pastor, M., J. Humanes, V. Vega, and J. Castro. 2001. Diseño y manejo de plantaciones de olivar. Consejería de Agricultura y Pesca Andalucía, Spain.

Rugini, E., G. Bongi, and G. Fontanazza. 1982. Effects of ethephon on olive ripening. J. Amer. Soc. Hort. Sci. 107:835-838.

Solé, M.A. and M. Florensa. 1997. Influencia de la fecha de recolección mecanizada en la producción del olivar de la variedad Arbequina en la comarca de 'Les Garrigues' (Lleida). Fruticultura Profesional. 88. Especial Olivicultura II: 113-117.

Tous, J., J. Lloveras, and A. Romero. 1995. Effect of ethephon spray treatments on mechanical harvesting and oil composition of Arbequina olives. J. Amer. Soc. Hort. Sci. 120:558-561.

Tous, J. and A. Romero. 1992. Determinación de la relación fuerza de retención/peso del fruto en 17 cultivares de olivo. Invest. Agr.: Prod. Veg. 7: 399-405.

Tous, J., A. Romero, and J.F. Hermoso. 2007. The hedgerow system for olive growing. Olea. 26:20-26.

Uceda, M. and L. Frias. 1975. Épocas de recolección. Evolución del contenido graso del fruto y de la composición y calidad del aceite. II Seminario Oleícola Internacional, Córdoba, Spain

Vitagliano, C. 1975. Ethylene-releasing compounds to loosen olive fruits for mechanical harvesting. HortScience 10:591

Yamada, H. and G.C. Martin. 1994. Physiology of olive leaf abscission induced by phosphorus. J. Amer. Soc. Hort. Sci. 119:956-963. 